\title{
CONFLICTS OF INTEREST FACED BY SOLICITORS INSTRUCTED BY INSURERS TO CONDUCT LITIGATION ON BEHALF OF INSUREDS
}

\author{
Chris Chapman and Jillian Mallon"
}

If an insurer pays on a claim for loss then the insurer, either by the terms of the insurance contract itself or by virtue of its equitable right of subrogation, becomes entitled to stand in the shoes of the insured and pursue any person causing the loss. That may involve the insurer instructing solicitors to issue a proceeding in which the insured will be named as the plaintiff. The insured's co-operation is required by the terms of the insurance contract. Although remunerated by the insurer, the solicitors will be on the record as solicitors for the insured as the named plaintiff. In the course of conducting the litigation and, in particular, in the course of interviewing the insured, it may come to the solicitors' attention that the insurer did have grounds for rejecting the claim. In addition, the insured's lack of co-operation in the prosecution of the claim may amount to a breach of the insured's contractual obligation to assist. In such instances, conflicts of interest arise. In addition, where the policy provides for a deductible which is other than nominal, decisions made as to the conduct of the litigation, in particular, decisions relating to settlement of claims, may impact differently on insurer and insured and give rise to conflicts of interest.

Part I of this article looks at conflicts faced by solicitors who, while acting for both insurer and insured, become aware of grounds upon which a claim under a policy could be rejected or, in the case of a claim which has already been accepted, could have been rejected. Part II examines a number of conflict problems which can arise in the conduct of litigation other than conflicts caused by the discovery of grounds for rejection.

- Barristers and Solicitors of the High Court of New Zealand. 


\section{THE QUESTION OF INDEMNITY}

\section{A The Problem}

Professional indemnity insurance policies typically contain provisions under which the insurer agrees to pay the costs of the defence of the claim against the insured and which gives the insurer the right to take over and conduct the defence of that claim. ${ }^{1}$ Under this kind of provision, where a claim is made against the insured and the insurer accepts that the insured is entitled to indemnity under its insurance policy for that claim, the insurer appoints and pays for a solicitor to act in the defence of the claim against the insured. The reason for these provisions is that: ${ }^{2}$

... the underwriters will always have a substantial financial interest in the outcome of the proceeding and, depending upon whether there is any "excess" and upon the size of the claim in relation to the sum insured, may have the only financial interest in the outcome of the litigation except to the extent that the insured may himself be called upon to pay in the event of the underwriters' insolvency.

In many cases the interests of the insured and the insurer will be in common. But there will frequently be situations where the interests of the insured and the insurer will conflict. This Part considers the situation where the insurer-appointed solicitor, while acting in the defence of the claim against the insured, discovers information indicating that the policy may not provide cover, or that a policy condition has not been met, or that an exclusion clause applies. Should the solicitor disclose this to the insurer?

If the insurer is the client of the solicitor the solicitor may be under an obligation to provide that information to the insurer since this information may enable the insurer to escape having to pay out anything to the claimant and to avoid the costs of defending or settling the claim on behalf of the insured. If the insured is the client of the insurer-appointed solicitor the solicitor may not be able to provide the information to the insurer since acting in the best interests of the insured would require the solicitor to maximise the prospects of insurance cover for the claim. ${ }^{3}$ If the solicitor acts for both the insurer and the insured her

1 See the examples in Appendix 1.

2 CE Heath Underwriting \& Insurance (Australia) Pty Ltd $v$ Campbell Wallis Moule \& Co Pty Ltd (1991) 6 ANZ Insurance Cases 61-071, 77,222.

3 See eg, Tyrrell $v$ Bank of London (1862) 10 HLC 26, 39, 40; 11 ER 934, 939, 940 "The client is entitled to the full and best exertions of the solicitor"; cited with approval in Law Society of NSW v Harvey [1976] 2 NSWLR 154, 170. See also rule 1.08 of the Rules of Professional Conduct for Barristers and Solicitors set out in Appendix 2 which provides that information disclosed by a client is confidential and privileged from disclosure and rule 1.09 which requires a practitioner to disclose to her client all information received by the client which relates to the client's affairs. In Black $v$ Taylor [1993] 3 NZLR 403, 409, the Court of Appeal said of these rules that: "An ethical code of this kind expresses the profession's own collective judgment as to standards to be expected of 
clients' interests may be in conflict. Before the solicitor makes a decision to disclose or not to disclose the information she must first know who her is client is and what the scope of her retainer is.

\section{B A Review of the Case Law}

\section{New Zealand}

This issue does not appear to have come before a New Zealand court.

\section{Australia}

In a ruling of the Law Society of New South Wales ${ }^{4}$ it was said that the insurerappointed solicitor had two clients, the insured and the insurer. The insured was the client of the solicitor once the solicitor filed a defence on behalf of an insured. This ruling is in line with decisions of the courts which have considered the issue.

One of those decisions is State Government Insurance Commission(S.A.) v Paneros. ${ }^{5}$ In that case the insured was the driver of a vehicle involved in an accident which injured his wife. The wife brought a proceeding against the insured for damages. Pursuant to the Motor Vehicles Act 1959 the insurer instructed solicitors (Ward and Partners), to conduct the defence of the claim against the insured. ${ }^{6}$

From a time shortly after the accident the insurer had a blood test of the insured which indicated that the insured may have been intoxicated at the time of the accident. It was not clear whether the insured had been drinking before or after the accident and the insurer needed information from the insured to establish this. The relevance of the information was for a plea of contributory negligence, which had been included in the defence, in that the insured's wife had agreed to travel with the insured in an intoxicated state. It was also relevant to whether the insured was entitled to cover under the policy. The solicitors obtained a statement from the insured in which he disclosed that he had been drinking steadily at a football club function in the hours leading up to the accident.

practitioners. While it does not impose legal obligations or have the force of law it is some indication of relevant public policy."

4 Referred to in Disney, Redmond, Basten \& Ross Lawyers (2 ed, Law Book Company Ltd, Sydney, 1986$) 775$.

5 (1988) 5 ANZ Insurance Cases 60-857; (1989) 5 ANZ Insurance Cases 60-940.

6 Section 125(1) of the Motor Vehicles Act 1959 provided: "125(1) An insurer may, on behalf of an insured person- (a) conduct any legal proceeding in respect of circumstances out of which a claim against the insurer has arisen, or may arise; (b) conduct and control negotiations in respect of any claim against the insured person; and (c) at any stage of those negotiations or proceeding pay, compromise or settle any claim against the insured person."

7 The facts are set out in most detail in the judgment of White $\mathrm{J}$ in the decision of the full court. 
The insurer settled the claim with the wife of the insured and subsequently brought a proceeding against the insured to recover the sum paid to the wife. Initially the solicitors acted for the insurer in this subsequent proceeding but they later withdrew.

The insured sought an injunction restraining the insurer from making any use of any information about the accident which he had provided to the solicitors. The court at first instance granted the injunction. On appeal the full court discharged the injunction. The full court relied on the wording of the statute under which the solicitors had been instructed and therefore provides limited assistance in considering the issues outside the statutory context. ${ }^{8}$ Lunn AJ who considered the matter at first instance does, however, discuss the issues.

For the insurer it was argued that as the insurer had instructed and paid Ward and Partners they were the solicitors for the insurer and not the insured when they acted in the defence of the claim brought by the wife of the insured. Lunn AJ accepted without any apparent analysis that the solicitors were acting for the insurer. His Honour did discuss whether the insured was also the client of the solicitors. He said:'

The solicitor and client relationship arose not because of a contractual retainer entered into between the defendant and Ward and Partners, but in the context of the special situation created by the Act. Where solicitors employed by an insurer have undertaken the conduct of the defence of an action brought against the insured by virtue of a contractual right to do so in the policy of insurance, the courts have accepted that there is a solicitor and client relationship between the insured and the solicitors...[T]he court appears to have accepted that a similar solicitor and client relationship existed between solicitors instructed by the insurer and the insured where there was a statutory right for the insurer to conduct the defence. ...The plain fact of the matter here is that in action 1930 of 1977 Ward and Partners were shown as the solicitors on the court record for the defendant. This combined with the fact that Ward and Partners had told the defendant, or had allowed him to believe, that they were acting on his behalf to defend his wife's action must mean that there was some solicitor and client relationship between them and the defendant. This does not mean that Ward and Partners could not also have been the solicitors for the insurer, but to say that they were does not thereby mean that they could not also have been the solicitors for the defendant.

8 In particular s 124(4) required the insured to furnish the insurer with information in relation to the claim as the insurer might reasonably require. Section 124(7) provided: "A notice or information given under this section shall be privileged from production or disclosure in any legal proceeding except proceeding under this Part." Proceedings "under this Part" included a proceeding brought by the insurer against the insured in the circumstances of this case.

Above n 5, 75,372-75,373. 
Having found that the solicitors acted for both the insured and the insurer Lunn AJ went on to find that the information that the insured was intoxicated at the time of accident was imparted to the solicitor in confidence and that legal professional privilege attached to that information. The court was satisfied that the information had only been disclosed to the solicitors in the belief that the information was to be used solely for the purpose of defending the claim brought by his wife against him. The court considered that this was not overridden by the provisions of the Motor Vehicle Act 1959 which required the insured to provide all information relating to the claim as the insurer might reasonably require.

The court further said: ${ }^{10}$

If I am incorrect in my conclusions above, it is possible that there was an estoppel operating against the plaintiff which would now preclude it from using the information in question. The plaintiff through its agent Ward and Partners in requesting the information from the defendant about the accident made an express representation to him in the letter of 6 January 1983 that such information was required for the defence of his wife's action, and implied that it was not for any other purpose.

As to what the solicitors should have done, the court found that there was no sufficient disclosure by Ward and Partners or the insurer to the insured of the circumstances giving rise to the potential rise to conflict of interest. The court said: ${ }^{11}$

At the very least the defendant [the insured] should have been properly warned of the potential conflict of interest if the solicitors were not to be in breach of their duty to him...In any event Ward and Partners took no steps to inform the defendant [the insured] of the potential conflict in which they found themselves. If they had given him an appropriate warning, or had satisfied themselves that he had received such a warning earlier from the insurer, they could probably have obtained the information in question from the defendant without being in breach of their duty to him.

The full court did not discuss whether the insurer-appointed solicitors acted both for the insurer and the insured although White $\mathrm{J}$ indicated that they did act for both the insured and the insurer. ${ }^{12}$ As to whether the insurer-appointed solicitors could disclose to the

10 Above n 5, 75,375.

11 Above n 5, 75,374-75,375.

12 See eg, above $\mathrm{n}, 76,118$, where White J said: "It had been plain to the courts and to the legal profession for more than half a century before $s 125$ was enacted that an almost insoluble conflict of interest existed between the insurer and the insured in circumstances such as this, a conflict which placed the solicitor (and counsel) acting for both parties in an intolerable position." 
insurer information adverse to the insured, White $\mathrm{J}$, at least, ${ }^{13}$ seems to have considered that were it not for the statutory provisions the information would have been privileged from the insurer. ${ }^{14}$ In his minority judgment, White J would have upheld the injunction prohibiting the insurer from making use of the information because the solicitors had not warned the insured that a conflict of interest existed, that rights of indemnity were reserved and a proceeding contemplated against him before they obtained the information from him that he had been drinking steadily before the accident.

Legislation also provided the answer in Kabadanis $v$ Panagiotou. ${ }^{15}$ In that case the plaintiff had brought a proceeding against the defendant for personal injuries caused by the discharge of a shot gun allegedly while the plaintiff was a passenger in the defendant's car. The defendant's defence was conducted by his insurer's solicitors. The plaintiff and the defendant both gave evidence that the shot gun had discharged inside the defendant's car. The solicitors for the defendant, however, called expert evidence which was accepted by the trial judge that the shot gun could not have discharged in the car. This meant that the accident was not within the defendant's insurance policy. The plaintiff appealed the trial judge's decision and one of the grounds of appeal was that the insurer-appointed lawyer could not conduct the defence in a way which was not in the defendant's interests. This ground of appeal was rejected by the Federal Court of Australia. Apart from it not being for the plaintiff to complain that the defendant's interests were being advanced the court said: ${ }^{16}$

Furthermore, the whole scheme of statutory liability insurance under the Motor Traffic Ordinance, as under similar legislation elsewhere in Australia, involves the right of the insurer to take control of proceeding in which the liability of the insured is in issue: see sec.68 of the Motor Traffic Ordinance 1936. The defendant's instructions to his solicitors and counsel must inevitably take this right into account. There is no authority in support of the proposition that the insurer may not take control of such proceedings in order to establish any state of facts which negates the defendant's liability, even one to which the policy plainly does not apply.

In CE Heath Underwriting E Insurance (Australia) Pty Ltd $v$ Campbell Wallis Moule $\mathcal{E}$ Co Pty $L_{t d}{ }^{17}$ the court did not discuss whether the solicitors acted for the insurer, the

13 Jacobs J and Prior J did not indicate what their views would have been if the statutory provisions were not in place.

14 See above $\mathrm{n} 5,76,120$, where White J considers that the statutory provisions made deep inroads into previously sacrosanct rights of silence, non-incrimination and confidentiality of communications to a solicitor.

16 Above n 5, 77,053.

17 Above n 2, 77,225. 
insured or both. The court did, however, say that the solicitors owed a duty of care to the insured. Quite what that would entail in this context is not discussed.

In Northumberland Insurance Company Ltd $v$ Castner ${ }^{18}$ the clerk of the solicitor appointed by the insurer learned from the insured that he had been drinking prior to a motor vehicle accident contrary to what he had stated in the accident report. In a claim by the insurer against the insured, the insured argued that what he had told the solicitor's clerk was privileged and could not be used as evidence against him. The court, however, considered that the policy which entitled the insurer to bring or defend a proceeding in the name of the insured and to have "the sole conduct of such a proceeding" meant that the relationship of solicitor and client did not exist to the extent that the insured's admission was privileged.

In Kennedy $v$ Cynstock Pty Ltd ${ }^{19}$ Kearney J considered that the policy could provide that the insured waives the solicitor-client relationship. In the absence of such a provision the solicitor owed duties to both the insurer and the insured. If the insurer in the course of the defence of the claim against the insured, considers that it is not liable to indemnify the insured the solicitor must advise the insurer and the insured to obtain independent legal advice. The solicitor must withdraw where there is a substantial risk that information given to a solicitor in confidence by the insured may be disclosed to or used by the insurer against the insured in the coverage issue.

Lunn AJ in Paneros and Kearney J in Kennedy were referred to with approval in Verson Clearing International Pty Ltd $v$ Ward \& Partners. ${ }^{20}$ In that case the insurer had appointed the solicitors to act on behalf of the insured in the defence of a claim for damages for personal injury arising out of an alleged industrial accident. If the claimant was an employee of the insured at the time of the accident the claim for common law damages could not succeed and the claimant was restricted to payments recoverable under workers' compensation legislation. But if the claimant was an employee of the insured this also meant that the insured was not entitled to indemnity under the policy. The solicitors appointed by the insurer obtained a report which concluded that the claimant was an employee of the insured. The insured was then asked to obtain its own representation in the damages claim against it. The insured sought production of the solicitors' file including a copy of the report obtained by the solicitors and their opinion on that report. ${ }^{21}$ It was common ground

18 (1975) 3 Queensland Lawyer 246 reproduced in part in Disney, Redmond, Basten and Ross, above n 4, 775777.

19 (1993) 3 NTLR 108.

20 Supreme Court of South Australia, 24/4/96, Burley J. Action no 601, 1996.

21 Production was sought under s 39(1) of the Legal Practitioners Act 1981 which provided: "39(1) The Supreme Court may, on the application of any person, order a legal practitioner or former practitioner to deliver up 
that when the solicitors were appointed they acted for both the insured and the insurer. ${ }^{22}$ The court noted that the insurer and the insured had the "same interest" 23 in respect of the defence available if the claimant was an employee of the insured. The court considered that the evidence was equivocal as to whether the report and the opinion had been obtained solely for the purpose of advising the insurer on indemnity or whether it had also been obtained in the conduct of the defence. In the absence of clear evidence from the insurer on this point the court considered it appropriate to proceed on the basis that the report had been obtained for the conduct of the defence. ${ }^{24}$ In these circumstances the report and the opinion was work carried out by the solicitor on behalf of the insured and therefore fell within the statute under which production had been sought. ${ }^{25}$

Thus the position in Australia seems to be that the insurer-appointed solicitor has two clients, the insurer and the insured. As to the scope of those retainers, and the solicitors' obligations in the event of conflict, in the context of claims arising out of motor vehicle accidents the legislation provides the solution. In the case of the Motor Vehicles Act 1959 (SA), which was the legislation with which the court in Paneros was concerned, that solution is that where the insurer-appointed solicitor obtains information from the insured which is in conflict with the insured's interests in so far as coverage is concerned the insurer is made a party to the proceeding brought by the injured party against the insured. The insured is entitled to be heard in the proceeding and to be separately represented by counsel at the cost of the insurer. The insured is liable to cross examination by the insurer. The findings at the trial are not binding against the insured in any subsequent proceeding brought by the insurer against the insured.

Where there is no relevant legislation the terms of the policy will be important. Where the terms are not decisive and the insured has provided information to the solicitor in confidence Cynstock, in contrast with Castner, indicates that the solicitor must advise both parties that a conflict has arisen and that the parties should obtain independent legal advice. Where the information is obtained from a third party while the solicitor is acting in the common interest of the insurer and the insured, Verson Clearing seems to indicate that it

papers- (a) held by the practitioner or former practitioner on behalf of the applicant; or (b) relating to proceedings taken to or work done by the practitioner or former practitioner on behalf of the applicant."

22 Above n 20, 2,4.

23 Above n 20,3.

24 Above n 20, 4.

25 Above $n$ 20, 5.

26 See ss 124, 124a and 125 of the Motor Vehicles Act 1959 (SA). 
is not inappropriate for the solicitor to pass this information on to the insurer and that the insured may also be entitled to the information.

\section{England}

In $\mathrm{Re}$ Crocker ${ }^{27}$ the insured, following a proceeding in which the insurer-appointed solicitor had admitted negligence on the part of the insured without his consent and judgment had been entered against him, sought the production for inspection of all the documents relating to that proceeding which was in the possession of the insurer-appointed solicitor. The court considered that the usual rule that the client was entitled to "access to all the documents which were concerned with the matter in which the solicitors were acting as such for him" ${ }^{28}$ was applicable. The court held that the insurer-appointed solicitors were "in all matters concerning the action" ${ }^{29}$ the solicitors of the insured.

The court noted that the insurer might also want access to the documents if, for example, "any question arises with regard to the rights under the policy as between [the insurer] and [the insured]", and this the court considered, was a possible reason for keeping the documents in the solicitors' possession. ${ }^{30}$ By implication the court appears to have accepted that the insurer-appointed solicitors were also the solicitors for the insurer and the insurer was entitled to access to the documents held by the solicitors in connection with the defence of claim against the insured even when a conflict arose between the insurer under the policy.

The insured in $R e$ Crocker brought a claim for damages against the insurer appointed solicitors. In this proceeding Sir Wilfrid Greene MR considered that the solicitors were acting in a matter in which the insured and the insurer had "a common interest" and that the terms of the policy meant that the insured was not entitled to require the solicitors to act according to the insured's instructions as in the usual solicitor-client situation. MacKinnon LJ considered that the insurer-appointed solicitors acted for both the insured and the insurer and in the event of a conflict on the tactics of the defence the solicitor had a duty to inform the insured of the conflict. ${ }^{32}$

27 [1936] Ch 696.

28 Above n 27, 903.

29 Above n 27, 903.

30 Above n 27, 702.

31 Groom $v$ Crocker [1938] 2 All ER 394, 400.

32 Above n 31, 416, 417. 
Brown $v$ Guardian Royal Exchange Assurance $\mathrm{Plc}^{33}$ concerned the question whether the insurers were entitled to discovery of the documents relating to the defence of the proceeding against the insured which were in the possession of the insurer-appointed solicitors. Included in these documents were the solicitors' notes of what had been said in a conference which the insurer believed might be relevant to their defence under the policy. The High Court upheld the insured's objection that the documents were the subject of legal professional privilege. The court of Appeal disagreed and found that the insurer was entitled to the documents.

In the High Court the insured had argued that the relationship between the insurer and the solicitors was not one of solicitor-client but rather some other contractual relationship. This was rejected by Judge Diamond QC in the High Court as being "somewhat meaningless and unreal". ${ }^{34}$ His Lordship considered that the solicitors owed contractual duties to the insurer which included making reports and giving advice which would enable the insurer to decide on the best tactics to be employed in the defence. His Lordship was also found that a solicitor-client retainer arose between the solicitors and the insured when the solicitors wrote to the insured and/or began to act for him to protect his interests and to act as his solicitor on the record if and when the proceeding was commenced.

In the Court of Appeal Hoffman LJ noted that there was no dispute that the insurerappointed solicitors were the solicitors for the insured. His Lordship did not need to consider whether the solicitors were also the solicitors for the insurer because the question of access to the documents was answered by the terms of the policy. Neill LJ considered that the policy and the instruction given to the insurer-appointed solicitors established a solicitor-client relationship both with the insured and the insurer. The solicitor-client relationship with the insured was for the purposes of defending the claim. The solicitorclient relationship with the insurer involved the insurer paying the solicitors' fee in return for which the solicitors had to report to the insurer about the progress of the case.

As to what the insurer-appointed solicitor should do in the event of a conflict the High Court indicated that the solicitor must simply advise both clients that a conflict has arisen and withdraw. The court referred to the principle that when two parties jointly employ the same solicitor, communications passing between either of them and the solicitor in her joint capacity, must be disclosed to the other. It considered it to be inapplicable, however, because it found that there were two separate retainers (rather than a joint retainer) under

33 The decision of Judge Diamond QC in the Queen's Bench Division (Commercial Court) was delivered on 31 July 1992. The High Court decision was appealed and is reported at [1994] 2 Lloyd's Law Rep 325.

34 The insurers had retained the solicitors through a letter from the brokers which stated "this matter has been referred to you by underwriters, and we shall be pleased to receive your report as soon as possible". 
which the solicitors owed separate and distinct duties to the two parties to the contract of insurance who had potentially opposing interests.

In the Court of Appeal the insurers argued that privilege could not exist between the parties because the insurer and the insured had joint or common interests. Reliance was placed in the dictum of Bridge LJ in Cia Barca de Panama SA $v$ George Wimpey $\&$ Co Ltd: ${ }^{36}$

If $A$ and $B$ have a common interest in litigation against $C$ and if at that point there no dispute between $A$ and $B$, then if subsequently $A$ and $B$ fall out and litigate between themselves and the litigation against $C$ is relevant to the disputes between $A$ and $B$, then in litigation between A and B neither A nor B can claim legal professional privilege for documents which came into existence in relation to the earlier litigation against it.

For the insured it was submitted that the duty to report to the insurers should be confined to matters relevant only to the claim against the insured and did not include matters relevant to the liability of the insurers under the policy.

The Court of Appeal did not find it necessary to consider whether there was a joint retainer or a common interest resulting in the application of the dictum in George Wimpey. This was because ${ }^{37}$ the policy specifically provided:

Where solicitors or other expert advisers are so employed their fees and expenses will be for the account of the Insurers who may require the solicitors' reports to be submitted directly to them.

It was found that this meant that any communications which the insurer-appointed solicitors received from the insured or from third parties concerning the subject matter of the

35 The High Court considered that the terms of the policy authorised these solicitors (in accordance with common practice) to submit detailed reports to the insurer advising them of the merits of the third party claim and of the best tactics to be employed in defending it. The policy did not, however, make provision as to communication when the solicitors' retainer had been terminated. Nevertheless it was considered implicit that in the event of a conflict resulting in the withdrawal of the solicitors, the insured had authority to withdraw his consent to the documents being forwarded to the insurers. The High Court concluded that: "Different considerations would prevail if the insurers had taken over the conduct of the defence under clause 4(a)(i) or if they had absolute conduct and control of the proceeding under the type of clause considered in Groom $v$ Crocker". The clause in Brown provided; "...the Insured shall procure that the Insurer's shall be entitle at their own expense at any time to take over the conduct in the name of Insured of the defence or settlement of any such claim...." The clause in Groom $v$ Crocker provided; "....the [Insurer] shall if in so long as it so desires, have absolute conduct and control of all or any proceeding against the insured.....and shall be entitled to use the name of the insured to enforce for the benefit of the [insurer] any order made for costs or otherwise, or to make to defend any claim for indemnity or damage against third parties."

[1980] 1 Lloyd's Law Rep 598, 615.

37 Above n 33, 326. 
claim were to be disclosed to the insurers even if the information also indicated that the insured was not entitled to cover under the policy. Neill LJ said: ${ }^{38}$

The policy and the instructions given to RPC [the insurer-appointed solicitors] established a tripartite arrangement on the following lines: (1) RPC became Mr. Brown's solicitors [the insured's solicitors] for the purpose of defending the claim. As far as the outside world was concerned the relationship was a usual one between a solicitor and his client and their communications were protected by legal professional privilege. (2) At the same time a separate relationship of solicitor and client came into existence between RPC and the insurers. The insurers became liable to pay RPC's fees and in return RPC became liable to report to the insurers about the progress of the case. (3) By accepting the benefit of legal representation made available in accordance with the terms of the policy Mr. Brown waived his right quoad the insurers to claim legal professional privilege in relation to communications about the claim between himself and RPC during the period that representation under the policy continued.

...It seems clear that something emerged at the conference which led RPC to believe there might be a conflict of interest between Mr. Brown and the insurers and that they should no longer continue to act. But while the representation under the policy subsisted RPC were under a duty to make a full and nor merely a partial report of how matters had progressed. Suppose the possibility of a conflict had come to light because of a statement obtained from another witness who was not only able to give evidence about a number of important matters of fact but who could also testify to Mr. Brown's state of knowledge at a relevant time. Is it to be said that the insurers were only entitled to have an edited version of that evidence?

The Law Society in England said in 1974: ${ }^{39}$

For the avoidance of doubt it is clearly desirable that a solicitor who is acting both for an insurance company and for the insured in relation to the same proceeding should advise both clients that he is acting on the basis that he will fully disclose to both clients matters of common interest coming to his knowledge. If this is not accepted as the basis for his instructions, then he should decline to act for the insured.

Thus the position in England appears to be that the insurer-appointed solicitor has two clients, the insured and the insurer. The solicitor acts for the insurer and the insured in their common interest in defending the claim against the insured. The relationship between the insurer and the solicitor on the one hand and the insured and the solicitor on the other is separate. Where the policy provides for reports to be submitted directly to the insurer this means that the insurer is entitled to receive from the solicitors information obtained from the 
insured or a witness about the claim against the insured even where the information may indicate that the insured is not entitled to cover under the policy. This may also be the case even where the policy does not expressly provide that reports may be made directly to the insurer since it is not clear from the reports of Re Crocker or Groom $v$ Crocker whether the policy in issue contained such a provision.

\section{United States}

A few courts have held that the lawyer's client is the insurer alone with the insured being only a nominal client. For example in Schumm $v$ Long Island Lighting Co ${ }^{40}$ the court ${ }^{41}$ considered it an unalterable fact the counsel herein serve but one master, the insurance carrier." ${ }^{42}$ The court reached its conclusion because inter alia the insured did not have any control of or any real confidential relationship with the assigned attorney; he did not have any right to determine or direct a settlement; and he had to comply with the conditions of his contract of insurance or be subject to a disclaimer of coverage.

Some courts have held that the lawyer acts for the insured alone. This view is thought to be gaining popularity in the courts ${ }^{43}$ and is the view taken by the drafters in a draft of The Restatement of the Law Governing Lawyers. ${ }^{44}$ Under this view the insurer is the employer of the lawyer and pays a fee, but is not the client. By way of example in Jackson $v$ Trapier ${ }^{45}$ the court said: ${ }^{46}$

[T] he primary interest of these attorneys in the instant case is to represent the defendant. Having once undertaken his defence, their allegiance is to him and they may not represent any other interest that may be adverse. The court recognizes that in most negligence cases counsel for the defendant is provided by an insurance carrier. Nevertheless, after such counsel is retained and appears for a defendant, he is obliged to represent the defendant. From that point on, the defendant is the client and not the insurance carrier even though the latter may have chosen the counsel and may be paying his fee.

4056 Misc 2d 913, 290 NYS 2d 423 (1968).

41 Which was a court at first instance.

4256 Misc 2d 913, 914.

43 C Silver and K Syverud "The Professional Responsibilities of Insurance Defence Lawyers" (1995) 45 Duke LJ $255,273$.

44 Proposed Final Draft No 1 (s 215). The position taken in this draft came in for both criticism and defence when it was considered in May 1995.

42 Misc 2d 139,140; 247 NYS 2d 315, 316 (1964). 
The position taken by many courts ${ }^{47}$ is that the insurer-appointed solicitor has two clients, the insurer and the insured. Under this approach a conflict of interest may arise and the courts have taken different views as to the proper course of action when this occurs.

One approach allows the insurer-appointed lawyer to continue to control the defence with the parties forgoing the collateral estoppel rule in the later trial on the coverage question. ${ }^{48}$ Thus, if in the trial of the claim against the insured, an issue is decided which is relevant to the coverage dispute, that decision does not effect the way the issue is decided in the trial on coverage.

Some New York courts have held that were the insurer-appointed lawyer discovers information which indicates lack of cover under the policy, that information is not privileged against the insurer. (This is the same approach as that argued by counsel in Brown and the approach which seems to have been favoured in Re Crocker.) In Carr and General Insurance Corp Ltd $v$ Goldstein, ${ }^{49}$ at a conference between the insurer-appointed lawyer and the insured, the insured admitted to not telling the insurer the truth as to the events giving rise to the claim. He signed a statement to this effect. The insurer sought a declaration that it was not liable to the insured on the grounds that the insured had failed to cooperate with the insurer. In finding that there had been a breach of the cooperation duty the court ruled that the lawyer could disclose what he had been told by the insured at the conference. This was on the basis that where a lawyer acts for two parties having a common interest, communications by the parties to the lawyer are not privileged in a controversy between those same two parties because the common interest forbids concealment by either from the other. The court stated: ${ }^{50}$

47 J K. Morris "Conflicts of Interest in Defending under Liability Insurance Policies: a Proposed Solution" [1981] Utah LR 457, 461; E M. Holmes "A Conflict-of-Interest Road Map for Insurance Defence Counsel: Walking an Ethical Tight rope Without a Net" (1989) 26 Willamette LR 1, 2; B Wunnicke Ethics Compliance for Business Lawyers (Wiley Law Publications, 1987) 329; and R E O'Malley "Ethics Principles for the Insurer, the Insured and Defense Counsel: the Eternal Triangle Reformed" (1991) 66 Tulane LR 511.

48 A D Windt Insurance Claims and Disputes: Representation of Insurance Companies and Insureds (1982) 176 citing Ferguson v Birmingham Fire Insurance Co 254 Or 496, 460 P 2d 342 (1969) and California's decisions including Gray $v$ Zurich Insurance Co $665 \mathrm{Cal} 2 \mathrm{~d}$ 263, 54 Cal Rptr 104, 419 P 2d (1966) which was subsequently disapproved in San Diego Navy Federal Credit Union $v$ Cumis Insurance Society Inc 162 Cal App 3d 358, 208 Cal Rptr 494 (1984).

49179 F Supp 888 (1959), affd 227 F 2d 162 (1960).

50179 F Supp 888, 890 (1959) and see eg, Liberty Mutual Insurance Co $v$ Engels 41 Misc 2d 49, 244 NYS 2d 983 (1963); Goldberg v American Home Assurance Co 80 AD 2d 409, 439 NYS 2d 2 (1981); Zurich Insurance Co v State Farm Mutual Automobile Insurance Co 137 AD 2d 401; 524 NYS 2d 202 (1981); Safter v Government Employers Insurance Co 95 AD 2d 54, 465 NYS 2d 20 (1983). 
Here the insurance company and the insured have a common interest in the defence of suits against the insured. Not only was the [insured's] statement to [the lawyer] not privileged from disclosure to the insurance company, it was, in fact, [the insured's] duty, imposed by his contract, to make a fair and frank disclosure to the insurance company because of the common interest in knowing the way in which the accident happened.

A different approach has been taken by Arizona courts. In Parsons $v$ Continental National American Group ${ }^{51}$ the lawyer after investigation disclosed to the insurer information which indicated that liability imposed on the insured would be within an intentional act exclusion in the policy. The lawyer continued to represent the insured under a reservation of rights. Later when the insured refused indemnity the court held that the insurer was estopped from refusing coverage. As to what the proper course would have been the court indicated that the lawyer should have notified the insurer that it could no longer act for it because of a conflict of interest. The court's view was that the lawyer had two clients but in the event of a conflict her higher or paramount duty was to the insured. ${ }^{52}$

A lawyer who does pass on information detrimental to the insured may be liable for punitive damages. This occurred in Lake Havasu Community Hospital, Inc v Arizona Title and Trust $\mathrm{Co}^{53}$ The insurer-appointed lawyer believed that the insured was attempting to settle the case but in such a way that would result in the insurer being the prime defendant in the damages suit. He informed the insurer of this urging it to write a letter "in relevantly strong language" to the insured pointing out that the policy would not cover losses suffered as a result of the conduct of the insured. The court considered that the lawyer had violated the rule in Parsons by continuing to act for the insured when his loyalty to it was divided and by passing on confidential and privilege information obtained from his client which could adversely affect its interest. This was so even though the insurer gave evidence that the lawyer was retained to represent its interest in minimising its liability under the policy as well as representing the insured in the defence of the claim against it. Further, the insured was also represented by its own lawyer because of the possibility that the loss would exceed the limits of the policy. The court considered that the lawyer's conduct constituted reckless indifference to the interest of the insured such that an award of $\$ 50,000$ punitive damages was warranted. The insurer was liable for this sum under the doctrine of respondent superior.

51113 Ariz 223, 550 P 2d 94 (1976).

52 The court had relied on an Arizona Ethics Opinion No 282 which adopted the position that "[a]lthough the opinions of the Committee state the lawyer represents both the insurer and insured, it is clear that his higher duty is to the insured...". 
The position taken by the Arizona courts is consistent with the American Bar Association's Informal Opinion No $1476(1981)^{54}$ which considered that the lawyer could not reveal to the insurer information she had gained from the insured or an independent witness which might result in the denial of coverage. To do so would be knowingly revealing a confidence or secret of the insured to her disadvantage. This was not always the view of the American Bar Association.

\section{Can the Insurer-appointed Solicitor Disclose Information to the Insurer which indicates that the Insured is not entitled to Cover?}

\section{Who is the client?}

The insurer-solicitor-insured tripartite relationship can conceivably involve solicitorclient relationships both with the insured and the insurer. Applying first principles a solicitor-client relationship would come into existence when a client agrees to receive and the solicitor agrees to provide legal services. ${ }^{56}$ In the context of the insurer-appointed solicitor, the solicitor, in defending the claim for the insured, is providing professional assistance. The solicitor-client relationship is not excluded merely because the insured does not select nor pay for the solicitor.

The general rule is that a person has the right to choose whom she will employ as a solicitor, and that a person has no authority, without specific authorisation, to retain a solicitor to act on another person's behalf. ${ }^{57}$ The policy provides the specific authorisation in the case of the insurer-appointed solicitor and the insured gives that authorisation when she accepts the policy of insurance or at the latest when she lodges a claim with the insurer who then appoints a solicitor.

As the court in Henke $v$ Iowa Home Mutual Casualty $\mathrm{Co}^{58}$ articulates, who pays the fee is not controlling. More important is the undertaking of the lawyer and the acceptance of her services by the insured. When the insured consults with the lawyer and allows her to appear in court on behalf of the insured, the insured has assented to the lawyer-client

54 See R Alexander-Smith, "Conflicts of Interest: Multiple Representations" (1983) 5-6.

55 See eg, the ABA Committee on Ethics and Professional Responsibility, Informal Opinion 822 (1965) referred to by O'Malley, above $n$ 47, 513 .

56 Cordery on Solicitors (8 ed, Butterworths, London, 1988) 49 states: "The retainer is the foundation upon which the relationship of solicitor and client rests. Without a retainer that relationship cannot come into being.... A retainer is a contract where by in return for the client's offer to employ the solicitor, the solicitor expressly or by implication undertakes to fulfil certain obligations."

57 Halsbury's Laws of England (4 ed, Butterworths, London) vol 44, para 88.

58249 Iowa 614, 619, 87 NW 2d 920, 924 (1958). 
relationship. If the insured does not wish to accept the lawyer's appointment, she can reject that appointment and relieve the insurer of its obligation to appoint and pay for the lawyer.

The solicitor-client relationship is not excluded because the insured may only be a "nominal" defendant. 59 Despite the fact that in many cases it will be the insurer who is the party with the most interest in the proceeding, the insured may retain an interest in the proceeding. It is the insured, and not the insurer whose reputation may be in issue. If the insurer-appointed solicitor has been acting under a reservation of rights by the insurer, then the insurer might at some point make a decision that the policy does not provide cover and discontinue funding the defence leaving the insured not as the nominal defendant but as the defendant in fact. Additionally, if the insurer becomes insolvent, the insured will be liable for the judgment obtained by the plaintiff.

Similarly the solicitor-client relationship exists between the solicitor and the insurer where the insurer appoints the solicitor to conduct the defence on behalf of the insured. The insurer seeks advice as to how the defence against the insured should best be handled and the solicitor provides that advice. Prior to taking over the conduct of the defence the insurer may have sought the solicitors advice on indemnity. Such a request and acceptance of that request would also give rise to a solicitor-client retainer.

\section{Scope of retainer}

There is no such thing as a general retainer. A solicitor's retainer is limited to the particular business in respect of which she is employed. ${ }^{60}$ Thus the scope of the retainer in the insurer-solicitor-insured situation will depend on what the parties have agreed to. Typically this will depend on the terms of the policy providing for the appointment of the solicitor. $^{61}$ Additionally it may be further defined by anything expressly agreed at the time of the appointment of the solicitor.

59 Courts are at times prepared to accept that the insurer, and not the insured, is the real party in the proceeding. Thus in Treiguts $v$ Tweedley [1969] VR 544 in a personal injury claim where the insurer had taken over the defence of a claim against the insured for damages for personal injury and the insurer was unable to answer interrogatories because the insured could not be located the court was prepared to excuse the failure to answer interrogatories. And see McCann $v$ Parsons (1954) 93 CLR 418 where a new trial was ordered where the insurer had discovered fresh evidence being that the insured had lied about being the driver of a vehicle involved in an accident; cf Wilson $v$ Raffalovich (1881) 7 QBD 553.

60 Cordery on Solicitors above n 56, 76, states: "Since a solicitor's authority springs from the retainer given to him by his client, his authority to act is limited by any special conditions imposed, and supplemented by any special authority conferred, by the retainer."

61 The point is made by Charles Silver in "Does Defence Counsel Represent the Company or the Insured?" (1994) 72 Texas LR 1583, 1604, that the policy is a contract between the insurer and the insured and that the retainer is a separate agreement under which the solicitor's responsiblities are defined. However, the terms of the policy are likely to form part of the terms of the retainer. See also above $n 43,270$. These authors take a similar 
It would be possible to agree that the solicitor acts for the insurer with respect to how the defence might best be run, whether the claim should be settled and if so what for, and on any questions relating to cover under the policy. It would also be possible to act for the insured in respect of providing a defence with the insured being made aware at the outset that any information relating to cover obtained while conducting the defence on behalf of the insured will be disclosed to the insurer.

Such an approach does not infringe the obligation imposed at common law that the client is entitled to the solicitor's best exertions. This is because within the scope of the retainer the solicitor will be able to use its best exertions.

Additionally the approach avoids the ethical problem presented by the conflict between rules 1.08 and 1.09 of the Rules of Professional Conduct for Barristers and Solicitors ${ }^{62}$ when a solicitor acts for more than one client (whereby on the one hand information imparted by a client to the lawyer is confidential and privileged and on the other hand the solicitor is obliged to disclose to her client all information that relates to the client's affairs). The ethical problem is avoided because rule 1.08 must have an implied exception ${ }^{63}$ where the client has agreed to disclosure. That exception must exist because a client always has the right to waive privilege 64 and, in agreeing at the outset that the information can be disclosed, the information would not be confidential. 65

In Brown the agreement to disclose was found in the policy. In Paneros it was found in the legislation. The typical professional indemnity policy current in New Zealand ${ }^{66}$ does not contain a provision similar to that in Brown. Nor is there legislation as in Paneros. It is possible that such an agreement could be implied from the usual provision that the insured must provide to the insurer matters relating to the circumstances of the claim ${ }^{67}$ at least with respect to coverage matters that are also relevant to the defence of the claim. Lunn $\mathrm{AJ}$ in Paneros, however, was not impressed by this argument where the legislation contained a similar provision.

approach to the responsibilities of the insurer-appointed solicitor as the approach taken in this paper in that they too analyse on a doctrinal basis who is the client.

62 See Appendix 2.

63 Comparable to rule 1.09 (ii).

64 See eg, Matthews and Malek Discovery (Sweet and Maxwell, London, 1992) para 9.02.

65 See eg, F Gurry Breach of Confidence (Clarendon Press, Oxford, 1994) 4, which states: "The confider must establish that the confidential information was disclosed in circumstances which imposed an obligation on the confidant to respect the confidentiality of the information".

66 See eg, the policy provisions in Appendix 1.

67 See eg, Appendix 1. 
In the absence of a specific policy provision the agreement could be obtained from the insured before the insurer-appointed solicitor agrees to act. This is consistent with the Law Society of England's approach. ${ }^{68}$ Before the insured's acceptance of this could be effective the solicitor would need to advise the insured to take independent legal advice. ${ }^{69}$ On the basis of the law relating to disclosure of matters of common interest and the policy provision requiring that the insured disclose information to the insurer that independant advice might be that the insured should agree to the arrangement. And, by making the terms of the retainer explicit at the outset, the possibility that the insured will disclose something to the solicitor which she believes will be kept confidential is minimised and the concerns of Lunn $\mathrm{AJ}$ in Paneros are addressed. 70

While this kind of agreement enables the solicitor to advise the insurer of matters relating to cover it does not answer the question of whether the insurer-appointed solicitor can continue to act for the insured in the defence of the claim against the insured for which indemnity has been sought. Where that information will also be in issue in the proceeding against the insured it will be inappropriate for the insurer-appointed solicitor to continue to act in the defence of the claim in a way which could result in exclusion of coverage unless the insurer and the insured agree that the trial will not give rise to an estoppel in respect of any subsequent proceeding between the insurer and the insured. ${ }^{71}$ The insurer and the insured might, however, agree to be bound by the findings in the claim against the insured. They might do so for reasons of cost because such an agreement might avoid the necessity of subsequent litigation between the insurer and the insured. Whatever arrangement is made the solicitor, in accordance with rule 1.07 of the Rules of Professional Conduct for Barristers and Solicitors, will need to have first advised the insured to take independent legal advice.

Where the parties have not agreed that the insurer-appointed solicitor can disclose to the insurer information relating to cover the question as to whether disclosure can be made will be decided by whether the information was obtained while the insurer was acting in the common interest of the insured and the insurer and/or under a joint retainer, or whether

68 See above $n 39$.

69 In San Deigo Federal Credit Union v Cumis Insurance Society Inc 208 Cal Rptr 494 (1984) the court referred to the need for "informed consent".

70 That is that the information is imparted in confidence and the solicitor represents that it is. See above nn 10, and 11.

71 The issue could also arise where information tended to show that the insured was liable under a cause of action to which the policy did not respond but not liable under any of the causes of action to which the policy did respond. 
the insured provided the information in confidence to the solicitor believing that the solicitor would not disclose the information to the insured.

As to the common interest/joint retainer rule, the rule is that where two different clients have separately instructed the same solicitor communications between the lawyer and one client maybe privileged against the other. Whether, however, the clients jointly instruct the same solicitor there is no privilege for the communication of one client with the lawyer as against the other client. The rule that there is no privilege of one against the other also applies where the parties did not jointly instruct the lawyer but did have a joint interest in the subject-matter of the communication. ${ }^{72}$ In Brown the High Court considered that there were separate retainers. In the Court of Appeal Neill LJ also considered that there were separate retainers.

In the context of the insurer-appointed solicitor whether there is a joint retainer or whether the High Court and Neill LJ are correct is probably not important. This is because the existence of a "common" or "joint" interest appears to have been accepted in Re Crocker and has also been that basis for the decisions of New York courts which have found that the insurer-appointed lawyer may disclose the information to the insurer which indicates that the insured does not have cover.

Outside the insurance context courts have allowed clients to access documents created at a time when there was no dispute between the two clients with the joint interest. ${ }^{74}$ These cases do not address the issue of whether the parties continue to have a "common" interest in communications where the communication is to the advantage of one client and to the disadvantage of the other. This is the situation where the communication is relevant to the defence of the claim against an insured but also indicates that the insured may not be entitled to cover.

72 See above $\mathrm{n} 64$, paras $8.07,8.61$.

73 Halsbury's Laws of England, above n 57, states: "Retainers by two or more person may be either joint or several, depending upon the intention of the parties and the nature of the business. In the former case each party is liable for the whole of the costs incurred for the benefit of himself or any of the other parties to it; while in the latter case each party is only liable for his proportion of the costs, incurred on behalf of all. Where, however, a retainer joint in form is in fact joint and several, and the work done ensures for the benefit of all, for instance in a partition suit, each party to it will be liable for the whole costs incurred." And see Hall v Meyrick [1957] 2 All ER 722 where the Court of Appeal considered whether there was a joint or several retainer in circumstances where two people together instructed a solicitor to prepare a will for each of them in which they conferred benefits on the other and where one of those clients paid the solicitor. It was found that the retainer was a separate one.

74 See eg, CIA Barca $v$ Wimpey [1980] 1 Lloyd's Law Reports 598 where two parties who had been in a joint venture. These parties had a common interest in a dispute between the joint venture company and a client; and Re Book \& Martin \& Co (Nominees) Ltd [1993] BCLC 328 which concerns on the one hand the sole directors and shareholders of a company, and on the other hand the company. 
The statement of the principle in CIA Barca which was relied on by counsel in Brown ${ }^{75}$ indicates that for the rule to apply there must be no dispute between the clients. In principle that would appear to be correct. For example if information gives rise to the possibility of running a defence in such a way that there is no cover under the policy the insured has no interest in conducting the defence in that way whereas the insurer may. It seems, however, that this is not the current thinking of the English Court of Appeal at least as demonstrated by their willingness to view the terms of the policy in Brown as authorising the disclosure of such information to the insurer.

Even if under the common interest rule the solicitor may disclose the information to the insurer, the solicitor will have a conflict of interest where the information gives rise to the possibility of running a defence in such a way as to exclude cover under the policy. The comments made above ${ }^{76}$ in relation to the conduct of the defence in the situation where the insured has agreed to the disclosure apply.

Assuming that the rule will be applied where the information obtained by the solicitor is relevant to the defence of the claim, it will not always be the case that the information relating to cover is also relevant to the defence of the claim. For example the solicitor may discover that the insured breached a duty of disclosure when she obtained the policy. The fact that the insured failed to disclose a matter relevant to the insurer's assessment of the risk may be unrelated and irrelevant to the proceeding against the insured. In that situation there is no common interest. The solicitor would have a conflict of interest in that the solicitor knows that she has been instructed on the basis that the insured has cover under the policy. The solicitor therefore knows that the information is information which the insurer has an interest in receiving. The solicitor also knows that to disclose the information to the insurer would be to the disadvantage of her other client, the insured.

The rule concerning no privilege between joint clients or clients with a common interest also does not apply where one of the clients has communicated to the solicitor outside the joint retainer and in an exclusive capacity. ${ }^{77}$ Thus where the insured makes it clear to the solicitor that the information is not to be disclosed to the insurer, the solicitor should not disclose that information to the insurer. Again the solicitor will have a conflict of interest.

75 See $\mathbf{n} 36$ above.

76 See earlier in this section.

77 See Matthews \& Malek, above n 64, para 8.61 citing Perry $v$ Smith (1842) 9 MW 681 where for example, Parke B said: "if the party employs an attorney who is also employed on the other side, privilege is confined to such communications as are clearly made to him in the character of his own attorney; and Re Book $\&$ Martin $\mathcal{E}$ Co (Nominees) Ltd above $n$ 71, 336 where Vinelott J said: "question of privilege will accordingly only arise in relation to documents with information within the categories I have described which come into their hands as solicitors for the third party only." 
In all of these situations (except where there has been an express agreement to the disclosure) the solicitor should act in accordance with rule 1.07 and advise the insurer and the insured that a conflict of interest has arisen and independent advice should be obtained. As to what the solicitor should say as to the area of conflict which has arisen the most prudent course for the solicitor will be to advise both clients simply that a conflict has arisen because of information received from the insured. Although the insurer may say that it is difficult for the insurer to obtain independent legal advice not knowing what it is obtaining advice on, the withdrawal of the solicitor is likely to suggest that a coverage issue has arisen. Given that the insured under the usual terms and conditions of policies is required to provide all information which the insurer may reasonably require of the insured the insurer could request that the insured provide the information.

\section{CONFLICTS ARISING FROM THE CONDUCT OF LITIGATION, DISPUTE RESOLUTION OR SETTLEMENT}

\section{A Potential for Conflicts of Interest}

The almost universal practice of the insurer appointing solicitors to act for the insured demonstrates, of course, that in the vast majority of cases, the interests of the insurer and the insured will coincide; a successful claim where the insured is named as plaintiff and a successful defence where the insured is named as defendant. In Groom $v$ Crocker MacKinnon LJ noted: ${ }^{78}$

If people act reasonably, it is obvious that the business method contemplated by the policy can be carried out with perfect smoothness and when I recall that for at least a century almost every case about a ship, both in the admiralty and in the commercial court, has been conduct by solicitors nominated by the underwriters or protection clubs I am the more convinced that this is so.

However, while it is inherent in the relationship that interests will usually coincide it is also inherent in the relationship that interests will sometimes diverge. Doubtless, in many cases minor diversions of interest are either overlooked or ignored. But there will be some divergences of interest (the circumstances of Groom $v$ Crocker being an example at the other end of the spectrum) which will have serious consequences for both insurer and the solicitors if not recognised and acted upon. 


\section{B Policy Provision for the Conduct of Litigation}

The insurance policy will usually provide for the conduct of litigation at the direction of the insurer. Relevant extracts from three examples of policies (two indemnity policies and one casualty policy) are set out in Appendix 1. In summary, the policies provide for:

(a) The insurer to take over the conduct of the defence in the event of a claim under a professional indemnity policy;

(b) The incidence of the costs of such a defence;

(c) The right of the insurer to be subrogated to the insured's rights upon payment of a claim;

(d) The insured's obligation to assist in the defence or in the prosecution of the subrogated claim;

(e) The distribution of any recoveries from some other party.

\section{Insured's Right to Influence the Conduct of Litigation}

Although it is clear that the solicitors act for both the insurer and the insured, the insured does not have a free hand to direct the conduct of the litigation as the insured would wish. In Groom $v$ Crocker Sir Wilfrid Greene MR held that a policy which provides for the insurer "if and so long as it so desires [to] have absolute conduct and control of all or any proceeding against the insured" has the effect of: ${ }^{79}$

[giving] the insurers the right to decide upon the proper tactics to pursue in the conduct of the action, provided that they do so in what they bona fide consider to be the common interest of themselves and their assured.

The insured's right to influence the conduct of the proceeding is correspondingly limited: ${ }^{80}$

The duty of the solicitor so nominated to the assured for whom he is to act cannot, of course, be the same as that which arises in the ordinary case of solicitor and client, where the client is entitled to require the solicitor to act according to his own instructions. The whole object and usefulness of these provisions would be defeated if the assured were to be entitled to interfere with the conduct of a proceeding in that way. The assured in my opinion is not entitled to complain of anything done by the solicitor upon the instructions, express or implied, of the insurers, provided it fall within the class of things which the insurers are, as between

79 Above n 31, 203.

80 Above n 31, 202, 203. 
themselves and the assured, entitled to do under the terms of the policy when properly construed.

Solicitors acting on the insurer's instructions and within the scope of the insurer's authority to conduct the proceeding, would, therefore, be entitled to ignore the insured's contrary wishes without exposing themselves to a claim for acting outside the authority of the insured as client, but that does not mean that there is no conflict of interest. A passage from the judgment of MacKinnon LJ indicates that, notwithstanding the authority vested in the insurer by the policy, a conflict of interest can arise: ${ }^{81}$

This means that the solicitor, nominated by the society, is the solicitor for the assured, who is his client. But he is also appointed by the society to protect its interest. If in regard to any question of tactics in conducting the litigation the solicitor has reason to discern a conflict, or possible conflict, of interest between the society and the assured, it is the duty of the solicitor to inform the assured of the matter. If the assured then insists on a course that the society disapproves, it can refuse to conduct or control the proceeding any longer and leave the assured to do so at his own cost, and at the risk, if the society are right in their view, of not being able to recover that cost under his policy.

\section{Insurer's Obligations of Good Faith}

The insurer owes the insured obligations to exercise its rights of control in good faith and in the insured's best interests. ${ }^{82}$ The insurer is not entitled to allow the conduct of the litigation to be influenced by the desire to obtain for itself some advantage altogether outside the litigation in question with which the insured has no concern. ${ }^{83}$

\section{E Solicitors' Duties to act in the Insured's Interests}

As solicitors for the insured as well as for the insurer, the solicitors owe duties to the insured as client to act in the insured's best interest. In Groome $v$ Crocker Scott LJ said: ${ }^{84}$

[T] he duty of the solicitor [is] to protect the client's interest and carry out his instructions in the matters in which the retainer relates, by all proper means. It is an incident of that duty that the solicitor should consult with his client in all questions of doubt which do not fall within the express or implied discretion left him, and should keep the client informed to such an extent as may be reasonably necessary according to the same criteria.

81 Above $n$ 31, 227, 228.

82 Mullins "Conducting an action on behalf of the insurer in the name of the insured (a case for schizophrenia)" (1991) 4 Insurance LJ 83, 85.

83 Above n 31, 203.

84 Above n 31, 222. 
Where the interest of insurer and insured diverge, the solicitors cannot act further without the fully informed consent (which will inevitably mean independent legal advice) of both parties.

If the solicitors act on instructions from the insurer where the instructions are outside the scope of the authority vested in the insurer by reason of the policy, then not only is the insurer liable to the insured for breach of the terms of the policy and for breach of good faith but the solicitors acting on the instructions are liable in breach of duty to the client: ${ }^{85}$

A solicitor who, acting on instructions express or implied from the insurer, does something to which the insurers, as between themselves and the assured, are not entitled to require the assured to submit, would in my view be acting beyond his competence and, if what he does is something which in the ordinary way would be a breach of duty to his client, he will be liable to the client accordingly.

Groom $v$ Crocker was a road accident case where the insured was clearly not liable but a deal was struck between the insured's insurance company and another insurance company which was implemented by the solicitors appointed by the insurer admitting the insured's liability.

The High Court and Court of Appeal held that the insurer was not entitled to require the admission of negligence when there was none and so was acting outside the terms of the insurance policy or in breach of its continuing obligations of good faith. The High Court and Court of Appeal then found that the solicitors were in breach of their contractual duty to the insured. There was an award of damages including for defaming the insured by wrongly agreeing to the entry of judgment.

It follows from Groom $v$ Crocker that, as a general principle, solicitors are at risk of liability as soon as any conflict of interest arises. Even provisions in the policy which appear to subordinate the interests of the insured to those of the insurer when a conflict arises would not entitle the solicitors to continue to act for both. The insured may well be entitled to take a different view of the extent to which her interests are subordinated by the terms of the policy and is entitled to be told of the need to obtain independent advice at that point.

The correct response of Messrs Crocker to their client insurer's instructions would have been to inform the insurer that admission of liability was not in the insured's best interests and unless the instructions were withdrawn Messrs Crocker would face a conflict of interest and be unable to continue to act for both the insurer and the insured and probably would be unable subsequently to act for either the insurer or the insured in relation to this 
litigation. Whatever the insurer's decision was, Messrs Crocker would have been obliged to inform the insured of the instructions, the objection to them and the insurer's decision.

\section{F Authority to settle}

Solicitors certainly have the insured's ostensible authority to settle a claim as between the insured and other parties to the litigation. Assuming that the solicitors have the insurer's instructions to settle to what extent do they also need the instructions of the insured? It is reasonably well established that the solicitors are not authorised by the insured to settle any liability in excess of the policy limit. ${ }^{86}$ It is reasonable to conclude that the solicitors have no authority to settle a claim which would involve the insured having to contribute an excess or deductible. It is also likely that the solicitors have no authority to settle a claim made in the name of the insured for an amount less than the insured is prepared to settle for since that would have the effect of preventing the insured ever recovering her excess from the wrongdoer. ${ }^{87}$ In effect, no settlement which has a financial consequence for the insured is possible without the insured's authority. A settlement on the insurer's instructions without the insured's authority is a breach of the policy by the insurer and a breach of a duty by the solicitors to the insured as client.

\section{G The Flow of Information}

Although there may be uncertainties ${ }^{88}$ as to whether information adverse to the insured can be communicated after a conflict of interest has been identified, it is likely that the insured, by agreeing in terms of the policy to allow the insurers "at any time to take over and to conduct in the name of the insured the defence or settlement of any such claim" must necessarily be taken to have waived rule $1.08^{89}$ in the absence of any conflict of interest. Similarly, the insurer, by appointing solicitors to act in the litigation with the certain consequence that the insured will become a client of the solicitors, has necessary waived rule 1.08 in the absence of any conflict of interest.

Accordingly, while there is no conflict of interest, there is a joint interest and the solicitors may communicate freely with both insurer and insured. The corollary of that is that there must be communication of such information. The strictness of the rule requiring disclosure is emphasised by the High Court decision in MacKaskell $v$ Benseman.

86 Hansen $v$ Marco Engineering (Aust) Pty Limited [1948] VLR 198.

87 Rule against splitting of causes of action - Spencer Bower and Turner, The Doctrine of Res Judicata (2 ed, Butterworths, London, 1969) 380.

88 See Part I of this paper.

89 See Appendix 2.

90 [1989] 3 NZLR 75. 
We understand that the practice of solicitors communicating primarily with the insurer and treating the insured as a witness is widespread. ${ }^{91}$ For the reasons set out in the previous paragraphs, it seems that the insured would be entitled to complain if the solicitors failed to keep the insured as well informed as the insurer unless there was some agreement which regulated the flow of information.

\section{$H$ Conflicts of Interest which may arise in the Course of the Conduct of the Litigation}

The following are some examples of where interests may diverge:

(a) The insured wants to settle the claim against her but the insurer wants to defend.

This is a situation which can arise where the claim is well in excess of policy limits and the likely quantum of settlement will clearly exceed policy limits. Delayed settlement will save the insurer's funding costs. The usual term of the policy forbidding an insured to negotiate a settlement on pain of the insurer rejecting a claim under the policy, puts the insured in an impossible position. ${ }^{92}$ In Australia, the Insurance Contracts Act 1984 (Cth) now provides that if required to do so by the insured, the insurer must within a reasonable time accept or decline a claim under the policy. If the insurer does not confirm acceptance of the claim under the policy, then it may not later defend the insured's claim in reliance upon the insured settling the claim without the insurer's permission.

The insured may also be anxious to settle where there is a continuing professional relationship between the insured and the claimant which relationship would be prejudiced by a "vigorous" defence of the claim by the solicitors appointed by the insurer.

(b) The insurer wants to settle the claim against the insured but the insured wants to defend.

This situation may arise where the insured has a deductible well below the level of the likely quantum of settlement and either the legal costs are for the account of the insurer or the deductible is inclusive of legal costs. Insurer and insured are then in the reverse of the position set out in the previous sub-paragraph. The insured does not wish to settle because the deductible is fixed and the delay in settlement means that the insured has the use of the money for longer (albeit at the cost to the insured of the expenditure of the insured's time in the preparation and conduct of the litigation and the risk of the stigma of the entry of

91 Mullins above n 82, 83 and see Kennedy $v$ Cynstock Pty Ltd above n 19, 112 where Kearney J stated: "In these circumstances I sometimes find that the solicitor instructed by the insurer wrongly treats the named defendant/insured, for whom he becomes solicitor on the record as more akin to a witness than a party to the action."

92 Distillers Company Biohemical (Aust) Pty Ltd v Ajax Insurance Company Limited (1973) 130 CLR 1 where the majority of the High Court of Australia held that the insured would be in breach of the policy condition not to make an admission without consent if it did settle the claims in question. 
judgment against the insured). With the size of the deductibles in some of the professional indemnity policies currently being written, a desire to keep the dispute unresolved for as long as possible is no longer the preserve of the irrational and the bloody minded.

(c) The insured wants the claim against her to succeed.

This situation may arise where a successful claim against the insured paid by the insurer produces some financial benefit for the insured. For example, where the claimant is a close relative.

(d) The insured wishes the claim to be pursued for the full amount of the loss but the insurer is content to settle for the loss paid under the policy exclusive of deductible.

Although it is the practice of some insurance companies to pay the insured the excess out of recoveries thus ensuring that it is the insurer which loses out if the recovery is less than $100 \%$, other insurers pay the excess over to the insured only after the insurer itself has been fully reimbursed. Solicitors acting in the former circumstances have no potential conflict of interest. Solicitors acting in the latter circumstances are faced with the insurer's willingness to accept a lower settlement in order to reduce costs and the insured's desire to see the full amount of the loss recovered at the insurer's cost.

\section{The QC Clause}

The impact of the potential conflicts of interest set out in the sub-paragraphs (a), (b) and (c) in section $\mathrm{H}$ above, is diminished by the effect of the $\mathrm{QC}$ clause commonly found in professional indemnity policies. The QC clause provides a mechanism for arbitrating differences between insurer and insured on the important question of whether to settle or defend.

As set out in Appendix 1, the first example of a QC clause provides that "neither the insured nor the underwriter shall be required to contest any legal proceeding unless a Queen's Counsel (to be mutually agreed upon by the insured and the underwriters) shall advise that such proceeding should be contested". Accordingly, if either the insurer or the insured wishes to settle and that wish is being resisted, the insurer or the insured, as the case may be, may invoke the QC clause. If the QC does not advise that the proceeding should be contested then the insurer or the insured respectively is entitled to have the proceeding settled. The second example is not strictly a QC clause because any "counsel" will do. The second example only provides for the insured to be excused an obligation to defend. Perhaps the insurer was satisfied that it had a right not to continue with a defence by the expedient of withdrawing its agreement to fund the defence.

Since the QC clause is going to be invoked against a background of disagreement between the insurer and the insured as to whether the claim should be defended in court or not, the operation of the QC clause may itself present the solicitors with a conflict of 
interest. Should both the insured and the insurer instruct independent firms of solicitors to ensure that the QC is made fully aware of their respective points of view on the issues on which the QC is required to advise? Additionally, if the insured under the first policy example is arguing that the claim should be defended and, therefore, requires the QC's opinion to that effect, does the insured have to meet the cost of the opinion?

If the insurer insists on going to trial in the face of a QC's advice that the proceeding should not be contested then the insurer would be in breach of the policy and if the solicitors acted on the insurer's instructions they would be in breach of their duties to the insured as their client. However, for tactical reasons, the solicitors will, in order to get the best possible settlement, be entitled to continue to give the claimant's solicitors the impression that the claim will be defended to the last.

Groom $v$ Crocker emphasises that the solicitors have a reasonably free hand in the conduct of the litigation. It is, therefore, unlikely that an insured could complain if the valued client's feathers had been more than a little ruffled by an aggressive defence.

If the insured insists on going to trial notwithstanding the QC's advice that the proceeding should not be contested then the insured would be in breach of the terms of the policy (although it will be in the insurer's interests to maintain the facade of preparedness to go to trial in order to get the best settlement terms). If the insured insists on going to trial then, as indicated by MacKinnon J in Groom $v$ Crocker, ${ }^{93}$ an option open to the insurer and those circumstances would be to leave the insured to conduct the litigation at her own cost and at her own risk. It is unlikely that the insured would wish to continue with the defence on those terms. If the insured did continue, the insurer would undoubtedly not be liable for the further legal costs, but there would still remain the difficult question of the extent to which the insurer was liable for any damages payable by the insured at the end of an unsuccessful defence. It would be impossible for the solicitors to continue to act for both insurer and insured even if the insured was willing to pay the solicitors for the further conduct of the defence. The issue of the extent of the insured's indemnity in the event of an unsuccessful defence may arise and information accumulated by the solicitors during the further conduct of the defence may be evidence of what the claim could have been settled for and therefore may be material to the issue of the extent of the insured's indemnity for the amount of the judgment. This issue appears not to arise under the second policy example. A defence by the insured under that policy against the insurer's wishes would not be a breach of the policy. While the insurer may not be liable for the cost of the continued defence, it would appear to be liable for the full amount of any judgment less any excess or deductible.

93 Above n 31, 228. 
An insured who wishes the claim to succeed may attempt to invoke the $\mathrm{QC}$ clause but, if the $\mathrm{QC}$ advises that the proceeding should be contested, may nevertheless attempt to undermine the insurer's defence. The point may quickly be reached where the insurer wishes to cancel the contract of insurance for breach of the insured's obligation to cooperate. As soon as the solicitors contemplate that they may be required to advise on avoiding the policy on those grounds, then the solicitors must refer the insured to other solicitors and deal with the insured in some respects as a witness advised by other solicitors. However, the solicitors in the litigation are still on the record as solicitors for the insured (at least until the policy is avoided for non-co-operation) and are probably obliged to keep the insured fully informed of matters of common interest.

\section{J Unrecovered Excesses}

Where an insurer wishes to settle for less than the full amount of the loss leaving the insured's excess uncovered, there may be several problems to overcome:

Does the insurer have control of the insured's claim against the wrongdoer before the insured has received a full indemnity for the loss?

The insurer owes continuing duties of good faith;

The solicitors may not have authority to settle for a lesser amount than the insured is prepared to agree to;

The solicitors may face a conflict of interest although sending the client insured away will undoubtedly prove adverse to the insurer's prospects for recovering anything.

In some policies, the order of priority is provided for ${ }^{94}$ but what is the position in the absence of such a specific provision?

Lord Napier and Ettrick $v$ Hunter ${ }^{95}$ concerned a subrogation claim to damages which 246 "names" had recovered in litigation against Outhwaite, their managing agents at Lloyds. The names had successfully sued Outhwaite for Outhwaite's negligent management of their underwriting. The House of Lords used a hypothetical name who had recovered damages of $£ 130,000$. However, the name had already received a payment under his stop loss insurance of $£ 100,000$. The name had had total losses of $£ 160,000$. The first $£ 25,000$ was the name's excess, the next $£ 100,000$ was the amount covered by the stop loss policy (and the name had received that in full) and the last $£ 35,000$ was in excess of the policy limits. The House of Lords held that the insurer's rights of subrogation applied after deduction of the $£ 35,000$

94 See, for example, the first policy referred to in Appendix 1.

95 [1993] 1 All ER 385 (HL). See also M Luey "Proprietary remedies in insurance subrogation" (1995) 25 VUWLR 449. 
uninsured loss. Accordingly, the insurer's recovered $£ 95,000$ of the $£ 130,000$ damages. The result of this case demonstrates that the answer to the question in subparagraph (a) is in the negative. It is not necessary that the whole of the insured's loss be paid before the insurer is subrogated to insured's claim.

The decision Lord Napier and Ettrick $v$ Hunter is relevant where the insured has been successful at trial or in settlement without the insurer's involvement or where the insurerappointed solicitors have taken the case to trial and obtained judgment for damages.

However, neither the specific clause nor the decision in Lord Napier and Ettrick $v$ Hunter avoids the conflict of interest where the insurer-instructed solicitors are attempting to negotiate a settlement which may not recover the insured's excess. On the contrary, a clause such as the example in appendix 2 and the decision in Lord Napier and Ettrick $v$ Hunter create the conflict of interest in these circumstances. Although the insurer is only subrogated to the rights of the assured in respect of the particular loss that they have paid ${ }^{96}$ nevertheless, the solicitors have the conduct of the whole of the claim. To the extent that the insurer is not subrogated to the claim, the insured must have a right to say whether or not that part of the claim may be compromised and if so on what terms. Accordingly, in such cases, it will still be necessary for the insured to agree to any settlement of the claim if such a settlement would amount to accord and satisfaction and prevent the insured pursuing the wrongdoer for the excess. The practical solution is for the insurer settling a claim to treat the excess as a first charge on recoveries.

\section{K Claims and Counterclaims}

In a case where an insured has issued a proceeding, the insured may be met not only with a defence but with a counterclaim. The counterclaim may be covered by the policy. The question then arises whether the insurer would be entitled to nominate solicitors to take over the conduct of the whole of the proceeding rather than just the counterclaim. The issue arose (albeit in a statutory context) in Club Motor Insurance Agency Pty Limited $v$ Swann ${ }^{97}$ where a plaintiff made a claim under his policy after being served with a counterclaim. It was common ground that the insured could not have one firm of solicitors representing the insured on the claim and another firm of solicitors defending the insured on the counterclaim. $^{98}$ In that case the full court of the Supreme Court of Victoria held that the insurer is entitled to take over the conduct and control on behalf of the insured insofar as the proceeding related to the counterclaim but (by a majority) that the insurer was not

96 Morely $v$ Moore [1936] 2 KB 359, 365.

97 [1954] VLR 754.

98 On this point see Carter $v$ Marine Helicopters and Others (1995) 8 PRNZ 674 where Williams J refused Marine Helicopters' application to be separately represented for its insured and uninsured losses. 
however entitled to take over the conduct and control of any other aspect of the claim nor is the insurer entitled to appoint its own choice of solicitors to represent the plaintiff in the proceeding.

This case also serves as a useful reminder that the insurer doesn't have to instruct solicitors to be entitled to control them. Solicitors instructed by the insured but subject (through the insured's obligations under the policy) to the insurer's control and subject to reporting obligations to the insurer, do not have the insurer as a client. Since the solicitors are not the insurer's solicitors they are not themselves at risk of conflict of interest. The insured may be at risk of a failure to comply with the policy obligations by instructing her solicitors to obey the insurer's instructions or to report to the insurer. The solicitors must, of course, give the insured proper advice as to the instructions that she ought to give them in order to comply with her obligations under the policy but, provided that proper advice is given, the solicitors themselves are at no risk. It is the insured which will face the consequences of a breach of the policy terms.

\section{Only some Bases of Liability are Covered.}

Where an insured is facing a number of causes of action some of which are covered by the policy and some of which are not, the insurer will obviously not be very interested in meeting the cost of defending the causes of action which are not covered by the policy. Indeed, if the causes of action are in the alternative, the insurer's financial interest will be best served if the uninsured causes of action are the points of weakest resistance. It is doubtful that the insurer's continuing obligations of good faith would require the insurers to defend causes of action which were not covered by the policy.

The solicitors instructed by the insured would find it impossible to conduct litigation partly on instructions from the insurer and the insured (in respect of causes of action covered by the policy) and partly on instructions only from the insured or, more accurately, uninsured (in respect of causes of action not covered by the policy). It seems that the only workable solution to this problem is for the insured to instruct her own solicitors and to seek reimbursement of any judgment covered by the policy and an appropriate proportion of the legal costs. This approach is analogous to the approach of the full court in Swann.

\section{CONCLUSION}

\section{A Generally}

The absence of any reported case in New Zealand and the very small number of cases reported in the UK and in Australia strongly suggests that conflicts of interest do not present major practical problems. As MacKinnon LJ noted "the business method 
contemplated by the policy can be carried out with perfect smoothness". ${ }^{99}$ It is hard to believe that anything approaching the facts of Groom $v$ Crocker would happen again. As the more recent cases in Australia and the UK demonstrate, the more difficult conflicts to resolve will arise where the insured has disclosed information adverse to the insured's interests vis $a$ vis the insurer.

\section{B Conflicts arising from the Discovery of Grounds for Rejection}

Despite the Court of Appeal decision in Brown $v$ Guardian Royal Exchange Assurance plc ${ }^{100}$ and particularly because of the absence of explicit provisions in policies in use in New Zealand for disclosure to the insurer of all information known to solicitors, it must be open to doubt that solicitors would be entitled to disclose to the insurer information adverse to the insured. The adverse information could be disclosed where the parties have expressly agreed at the outset that it may be disclosed. In the absence of such an agreement, where the insured begins to disclose information adverse to her interests then the prudent course is for the solicitors to terminate the interview and advise the insurer and the insured to seek independent advice.

The cover issue which has arisen then has to be addressed before the solicitors appointed by the insurer can continue with the litigation. If the insurers confirm acceptance of the claim then the solicitors can continue as before. Alternatively, the insurer may reject the claim under the policy or, possibly, reserve its rights. If the claim is rejected and the insured is a defendant the insured will have to instruct her own solicitors in the defence. If the claim is rejected and the insured has already been paid and the solicitors are pursuing claims under rights of subrogation, then the insurer may abandon pursuit of the claim and sue the insured for the recovery of the claim settlement. If the insurer reserves its rights and elects to continue with the defence or the claim, as the case may be, then the insured will need to retain her independent advice throughout and the insurer-appointed solicitors' access to the insured will be via her own solicitors.

\section{Conflicts arising from the Conduct of Litigation Dispute Resolution or Settlement}

In the absence of a $\mathrm{QC}$ clause in indemnity policies, there would be scope for disagreement as to whether the claim should be defended or not. However, the invocation of the QC clause will resolve most of these disagreements.

The solution to conflicts arising in litigation where the policy covers only some of the areas in dispute between the parties appears to be to have the litigation conducted by the insured's own solicitors but subject to the control of the insurers in respect of those parts of

99 Above n 31, 228.

100 Above $n 33$. 
the litigation which may result in liability covered by the policy. No doubt the insurers would be advised by their own solicitors throughout such litigation. Undoubtedly this is cumbersome and inconvenient but it appears to be the only way of avoiding the conflicts which are likely to arise in such cases.

There is a potential difficulty in relation to the insured's excess or deductible in the absence of a specific provision such as the example in Appendix 1. The conflict does not arise where damages are recovered by the insured (either in litigation or by settlement) without the insurer's involvement. In such cases, the insurer comes along later asking for its share. In such dispute the insured and the insurer are represented by their respective solicitors. Neither is a conflict likely to arise where the claim is taken to trial by the insurer-appointed solicitors since the solicitors' role as solicitors for the insured is all but finished by the time that there is a judgment for less than the full amount of the claim. In arguments over whether the excess should be paid first out of the judgment proceeds the insured can instruct her own solicitor. There is, however, a real problem where the solicitors are attempting to negotiate a settlement. Without the insured's permission, they could not negotiate a settlement which would shut out the insured's right to sue for the excess.

\section{APPENDIX 1}

\section{Examples of Relevant Policy Provisions}

Collective policy of professional indemnity insurance (primary layer) for barristers and solicitors, underwritten by CE Heath Underwriting and Agency Services (NZ) Limited

\section{- Operative clause}

The insured (as defined) having presented to the underwriters a signed proposal form bearing the date shown in item 7 of the schedule and containing particulars and statements which are hereby considered to be the basis of this insurance and incorporated herein and having paid the premium shown in the schedule it is hereby agreed:

The underwriters shall indemnify the insured (as defined) to the extent and in the manner detailed herein against any claim or claims first made against them and notified to the underwriters during the period of this policy as specified in the schedule arising from any civil liability incurred in connection with the provision of professional services (as defined). 


\section{- Deductible}

The amount specified as the deductible in item 9 of the schedule shall be borne by the insured at their own risk and the underwriters' liability shall only be in excess of this amount.

All recoveries and payments received in connection with a loss settlement shall be applied to the underwriters' benefit in priority to the specified deductible but not in priority to any additional sum beyond the limit of indemnity required to be contributed by the insured to dispose of a claim.

If the deductible shown in the schedule is described as inclusive of costs the insured shall pay to the underwriters the amount of any costs or expenses incurred by the underwriters as a consequence of their taking over and conducting in the name of the insured the investigation, defence or settlement of any claim pursuant to condition 8(a) but in respect of such claim the amount specified as the deductible in item 9 of the schedule shall abate by the amount of costs or expenses so paid by the insured.

\section{- Conditions}

(a) The insured shall not admit liability for, or settle any claim or incur any costs or expenses in connection therewith, without the written consent of the underwriters who shall be entitled at any time to take over and to conduct in the name of the insured the defence or settlement of any such claim. Nevertheless neither the insured nor the underwriters shall be required to contest any legal proceedings unless a Queen's Counsel (to be mutually agreed upon by the insured and the underwriters) shall advise that such proceedings should be contested.

(c) The insured shall on request give to the underwriters or their authorised representatives all such information and assistance as they may reasonable require.

(h) Subrogation

It is hereby agreed that, if any payment is made under this policy in respect of a claim, and the underwriters are thereupon subrogated to all the insured's rights of recovery in relation thereto, the underwriters shall not exercise any such rights against any present or former partner, employee or person under a contract of service with the insured unless the claim has been wholly or partly brought about by the dishonest, fraudulent, criminal or malicious act or omission of such person.

Professional indemnity insurance policy for members of Justicia Mutual Association Incorporated underwritten by FAI (NZ) General Insurance Company Limited 


\section{- Insuring clause}

1 The company shall, subject to the terms of this policy, indemnify the insured against liability for losses arising from claims first made against the insured during the period of insurance and notified to the company during this period by reason of any act, error or omission committed or omitted or alleged to have been committed or omitted by the insured.

2 The company shall pay all costs and expenses incurred with its written consent in defending or settling any claim made under this policy, provided that if the insured has to pay an amount in excess of the amount of indemnity available under this policy to dispose of a claim then the company's liability for costs and expenses shall be such proportion as the amount of indemnity available to the insured bears to the amount paid to dispose of the claim.

3 The company will indemnify the insured for claims up to the limit of indemnity referred to in the schedule, provided that the liability of the company hereunder shall not exceed in the aggregate for all claims under this policy (including claims covered by any of the extensions for which limits are stated in the schedule) the aggregate limit of indemnity stated in the schedule. Costs and expenses are not to be regarded as claim payments for limit of indemnity.

4 In respect of each claim made against the insured, including claimants costs and all costs and expenses incurred in the defence or settlement of each claim, the amount of the excess specified in the schedule shall be borne by the insured and the company shall only be liable to indemnify the insured for that part of any claim which is over and above the excess.

\section{- Conditions}

1 (a) The insured shall not admit liability for or settle any claim or incur any costs or expenses in relation to a claim without the written consent of the company which shall be entitled to take over and conduct the defence or settlement of any claim in the name of the insured.

(b) The insured shall not be required to contest any legal proceedings unless counsel (to be mutually agreed upon by the insured and the company) shall advise that such proceedings should be contested.

2 As a condition precedent to their rights under this policy the insured shall:

(b) Upon request give to the company such information and assistance, including where necessary a written declaration, as to such matters as the company 
may reasonably require to investigate the circumstances and conduct the defence of any claim.

\section{Waiver of subrogation}

If any payment is made under this policy in respect of a claim and the company is thereupon subrogated to all the insured's rights of recovery, the company shall not exercise any such rights against any present or former partners, directors or employees of the firm unless the claim has been brought about or contributed to by the dishonest, fraudulent (whether actual or constructive), criminal or malicious act(s) or omission(s) of such person(s).

\section{NZI "Peace of Mind" house insurance}

\section{- After your claim is accepted}

After we have accepted a claim on this insurance (either in whole or in part), we have the right to take over in full any legal right of recovery which you have. If we do this, we may exercise these rights for our own benefit and at our own expense, and you must fully co-operate to allow us to do this.

\section{APPENDIX 2}

\section{Relevant Ethical Rules}

Rules of professional conduct for barristers and solicitors (fourth edition 1996) updated 1995/6:

\subsection{Rule}

In the event of a conflict or likely conflict of interest among clients, a practitioner shall forthwith take the following steps:

(a) advise all clients involved of the areas of conflict or potential conflict;

(b) advise the clients involved that they should take independent advice, and arrange such advice if required;

(c) decline to act further for any party in the matter where so acting would disadvantage any of the clients involved.

Once a situation of the type described in paragraph 1.07(1)(iii) arises, it is not acceptable for practitioners in the same firm to continue to act for more than one client in a 
transaction, $^{101}$ even though a notional barrier known as a Chinese Wall may be or may have been constructed. Such a device does not overcome a conflict situation.

\subsection{Rule}

Information communicated to a practitioner by a client or otherwise received by a practitioner on behalf of a client, is confidential and, with certain statutory exceptions, privileged from disclosure. ${ }^{102}$

\subsection{Rule}

In most circumstances, a practitioner is bound to disclose to the client all information received by the practitioner which relates to the client's affairs. There are certain exceptions which includes cases where:

(i) such disclosure is prohibited by an order of a court or other competent body;

(ii) the client consents to non-disclosure;

(iii) the practitioner has inadvertently received information which if disclosed to the client, could be hurtful or damaging;

(iv) on humanitarian grounds, the practitioner should exercise a discretion not to disclose the information.

101 Re a firm of solicitors [1992] 1 All ER 353, 364.

102 Above $n 101$. 